\title{
Growth Performance of Sea cucumber Holothuria scabra Juvenile in Different Initial Size of Pond Culture in Lombok, Indonesia
}

\author{
Lisa Fajar Indriana ${ }^{1, *}$ and Muhammad Firdaus ${ }^{1}$ \\ ${ }^{1}$ Research and Development Division for Marine Bio Industry \\ Indonesian Institute of Sciences LIPI \\ Jl. Raya Senggigi, Teluk Kodek, Pemenang, North Lombok, Indonesia 83352
}

\begin{abstract}
Sea cucumber Holothuria scabra has high market value and demand, consequently its stock has sharply declined due to overexploitation. Aquaculture of sea cucumbers is a key to conserve and to restore the decreasing population while producing them for commercial purpose. The obstacles in scale-up production are still need to be addressed in nursery stage, juvenile release techniques and grow out which can be implemented in pond culture. Growth performance of $H$. scabra juvenile cultured in floating hapas was investigated in pond in Sekotong, West Lombok. In 12 weeks of field trial, the effect of three different initial groups of juvenile: small $\left(1.42 \pm 0.01 \mathrm{~g} \mathrm{ind}^{-1}\right)$, medium $\left(3.42 \pm 0.02 \mathrm{~g} \mathrm{ind}^{-1}\right)$ and big $(7.77 \pm$ $\left.0.02 \mathrm{~g} \mathrm{ind}^{-1}\right)$ were tested on their growth and survival by Completely Randomized Design. The result showed both Specific Growth Rate and Weight Gain were higher in small group $\left(2.57 \pm 0.11 \% \mathrm{od}^{-1}\right.$ and $2.57 \pm 0.11$ $\%$, respectively). The highest survival rate was in the biggest initial size group. Pond in Sekotong, West Lombok is potential for nursery and grow out of $H$. scabra juvenile.
\end{abstract}

\section{Introduction}

Indonesia ranks on the top of FAO's list for its captured sea cucumber with an average annual catch of 5.003 ton in 2009-2014 [1]. Sandfish Holothuria scabra is one of the highest demand for tropical sea cucumber species [2-4]. On the other hand, H. scabra stock has sharply decreased due to overexploitation $[1,5]$. Development of sea cucumber farming has been considered to be a prime concern sector in fisheries industry [6]. Thus, aquaculture of sea cucumber is a key to conserve and to restore the declining population whereas producing them for commercial purpose $[1,7]$.

H. scabra hatchery has been developed in Marine Bio Industry LIPI in Lombok Indonesia since 2011. According to [8] several steps to produce $H$. scabra were broodstock collection and maintenance, spawning and larvae rearing, settlement phase and early juvenile rearing also nursery and grow out of juvenile. In addition, after produced larvae successfully, the issues concerning nursery, release and aspects of juvenile growth in the wild are need to be addressed to increase production significantly.

\footnotetext{
*Corresponding author: lisaindriana23@gmail.com
} 
In Lombok, farmers usually use earthen ponds to grow out shrimp, milkfish, and producing salt. Introduction of new commodity is needed to revitalizing idle ponds, [6] reported that besides pen culture and sea ranches, grow out of $H$. scabra juvenile can be implemented in pond culture. The issues in scaling up the production in ponds lie in the nursery phase, juvenile release and grow-out techniques implemented in grow out system, both monoculture and IMTA [7, 9, 10]. Furthermore, to increase productivity, [4] studied that many coastal communities applied intensive mariculture practice using floating cages and pens. This study was carried out to determine the effect of initial juvenile size on growth and survival of $H$. scabra juveniles in floating hapas in earth pond.

\section{Materials and Methods}

\subsection{Source of Juvenile}

All $H$. scabra juveniles were produced at hatchery facilities of Marine Bio Industry LIPI in North Lombok. The juveniles were reared in tanks in the laboratory after settlement phase until they reached approximately minimum weight $1 \mathrm{~g}$ prior to transfer in the earth pond. Three size classes of juveniles were used for initial stocking in the experimental pond: small $\left(1.42 \pm 0.01 \mathrm{~g} \mathrm{ind}^{-1}\right)$, medium $\left(3.42 \pm 0.02 \mathrm{~g} \mathrm{ind}^{-1}\right)$ and big $\left(7.77 \pm 0.02 \mathrm{~g} \mathrm{ind}^{-1}\right)$. All groups of juveniles were sourced directly from the hatchery and used in the experiment. They were transported for $1.5 \mathrm{~h}$ to study site in plastic bags with saline water and oxygen.

\subsection{Experimental design}

Experiment was carried out from August to November 2015 in Sekotong, West Lombok, West Nusa Tenggara. Grow out of juvenile was conducted in former shrimp pond for 12 weeks rearing period. The floating hapas were constructed from mesh (length $=100 \mathrm{~cm}$, width $=100 \mathrm{~cm}$, height $=50 \mathrm{~cm}, 2 \mathrm{~mm}$ pore size) sewn on to PVC frame and covered by fishing net to protect from predators like birds and crabs. The hapas were positioned within earth pond with floating method following daily tidal cycle. All hapas were soaked in the pond for a week to grow biofilm. Juvenile in each group were distributed in to hapa with stocking density 15 ind hapa ${ }^{-1}$ using a Completely Randomized Design (CRD) with 3 initial size groups and 3 replicates per treatment. Sampling was conducted every two weeks.

\subsection{Growth and Survival}

Wet weight was used as an indicator of juvenile growth. At the end of the experiment, the Survival Rate (SR), the Weight Gain (WG), the Specific Growth Rate (SGR) and the Total Biomass (TB) of juveniles were estimated following equations below:

$$
\begin{gathered}
\text { Survival Rate }(\%)=(\mathrm{N} t / \mathrm{NO}) \times 100 \% \\
\text { Weight Gain }(\%)=(\mathrm{Wt}-\mathrm{WO}) / \mathrm{WO} \times 100 \% \\
\text { Specific Growth Rate }\left(\% \text { day }^{-1}\right)=100(\ln \mathrm{Wt}-\ln \mathrm{WO}) / \mathrm{t} \\
\text { Total Biomass }(\mathrm{g})=W t \times \mathrm{Nt}
\end{gathered}
$$

Where Nt is the final number and NO is the number of juveniles. Wt and W0 are the final and initial weight of juveniles respectively, $\mathrm{t}$ is the duration time of the experiment (days). 


\subsection{Statistical analysis}

Data were analyzed with ANOVA at a significance level of 0.05 using the SPSS software (version 25). The Tukey post-hoc test was applied to investigate any significant difference between treatments.

\section{Result and Discussion}

\subsection{Effect of different initial size on Holothuria scabra juvenile growth}

Growth performance of $H$. scabra juveniles in three different initial size are presented in Table 1. The SGR of $H$. scabra juveniles in small, medium and big group was $2.57 \pm 0.11$, $1.75 \pm 0.29$ and $1.15 \pm 0.15 \%$ day $^{-1}$ respectively. However, the SGR values during the whole study period were significantly affected by initial size group $(\mathrm{P}<0.05)$. Growth rate value has no significant different in three treatments (range $0.13 \pm 0.01$ and $0.15 \pm 0.03 \mathrm{~g} \mathrm{day}^{-1}$ ). The highest WG was $766.21 \pm 79.22 \%$ in small group, however, WG of medium and big group were lower ( $343.41 \pm 113.49$ and $163.79 \pm 33.46 \%$, respectively).

Table 1. Growth parameters of three different initial size groups of Holothuria scabra juveniles in pond

\begin{tabular}{ccccccccc}
\hline $\begin{array}{c}\text { Initial Size } \\
\text { Group }\end{array}$ & $\begin{array}{c}\text { Initial Weight } \\
(\mathrm{g})\end{array}$ & $\begin{array}{c}\text { Final Weight } \\
(\mathrm{g})\end{array}$ & $\begin{array}{c}\text { Survival } \\
\text { Rate }(\%)\end{array}$ & $\begin{array}{c}\text { Total } \\
\text { Biomass }(\mathrm{g})\end{array}$ & $\begin{array}{c}\text { Specific Growth } \\
\text { Rate }\left(\% \text { day }^{-1}\right)\end{array}$ & $\begin{array}{c}\text { Growth Rate } \\
(\mathrm{g} \text { day }\end{array}$
\end{tabular}

Some studies focused on nursery production phase such as [11] who carried out first mono species nursery trials using hapa net in marine ponds in Vietnam. They found out that growth rate was 0.02 gday $^{-1}$ with final mean weight $1 \mathrm{~g}$. In other studies, [12] reported that growth rate was 0.83 gday $^{-1}$. In the Philippines, the growth rate was 0.01 gday $^{-1}$ with final size was $0.6 \mathrm{~g}$ and 0.052 , gday $^{-1}[7,13]$. The growth rate in nursery rearing in New Caledonia was 0.90 gday $^{-1}[14]$ and 0.03 gday $^{-1}[10]$.

\subsection{Mean Weight}

The mean weight of $H$. scabra juveniles in three different initial size experiment for 12 weeks are provided in Figure 1. Overall, the average weight of the small and medium group increased until $10^{\text {th }}$ week and decreased in the final week. However, weight average was rising during $6^{\text {th }}$ week of rearing period in big group and declined in $8^{\text {th }}$ week then increased until the end of experiment. Final mean weight in big group was higher than small and medium group, same situation also occurred in survival. In this condition, juveniles in each hapa were in highly competition for food resources and space. It is important to sort the juveniles by their size because they tend to grow in different rates [15]. 


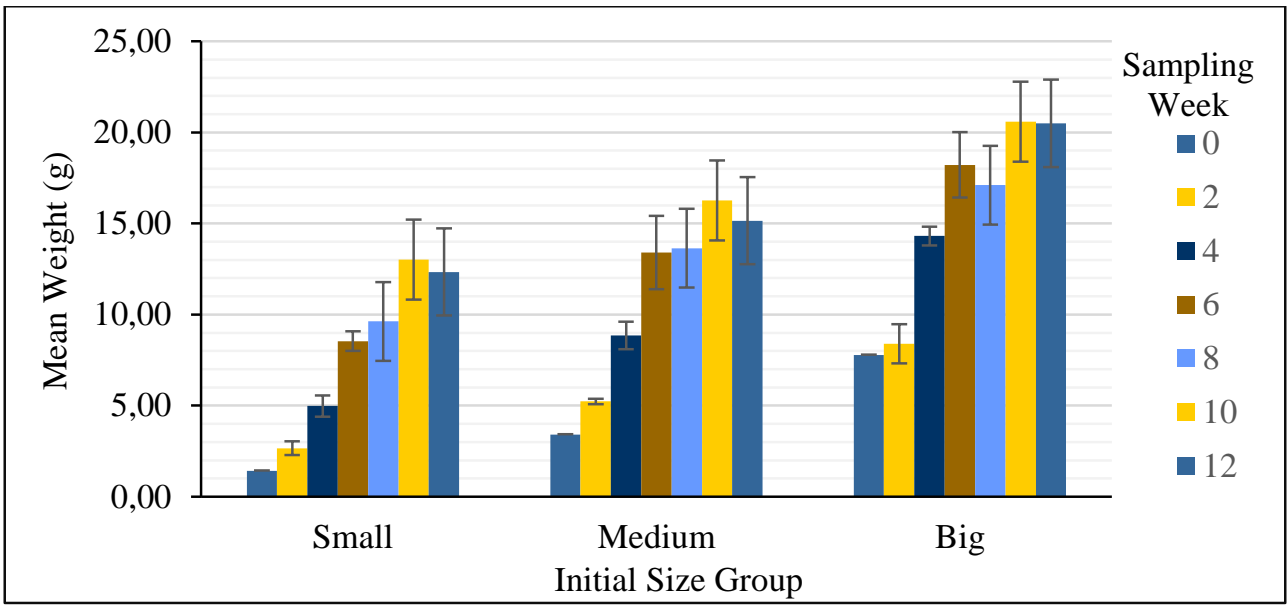

Fig 1. Mean weight of three different initial size groups of Holothuria scabra juvenile

\subsection{Biomass}

Total biomass of three different initial size groups of $H$. scabra juvenile is shown in Figure 2. As a general trend, after 12 weeks of experiment, biomass in small group increased from initial week until $10^{\text {th }}$ week with the final number $151.37 \pm 2.93 \mathrm{~g}$. In addition, total biomass in medium and big group rose from $1^{\text {st }}$ week to $6^{\text {th }}$ week, they decreased in $8^{\text {th }}$ but increased in $10^{\text {th }}$ week. Total biomass in both initial classes were $173.44 \pm 29.95$ and $301.03 \pm 45.69 \mathrm{~g}$. The advantage of releasing juvenile earlier and smaller size from hatchery is to develop behavioural conditioning in the wild for long term culture [16].

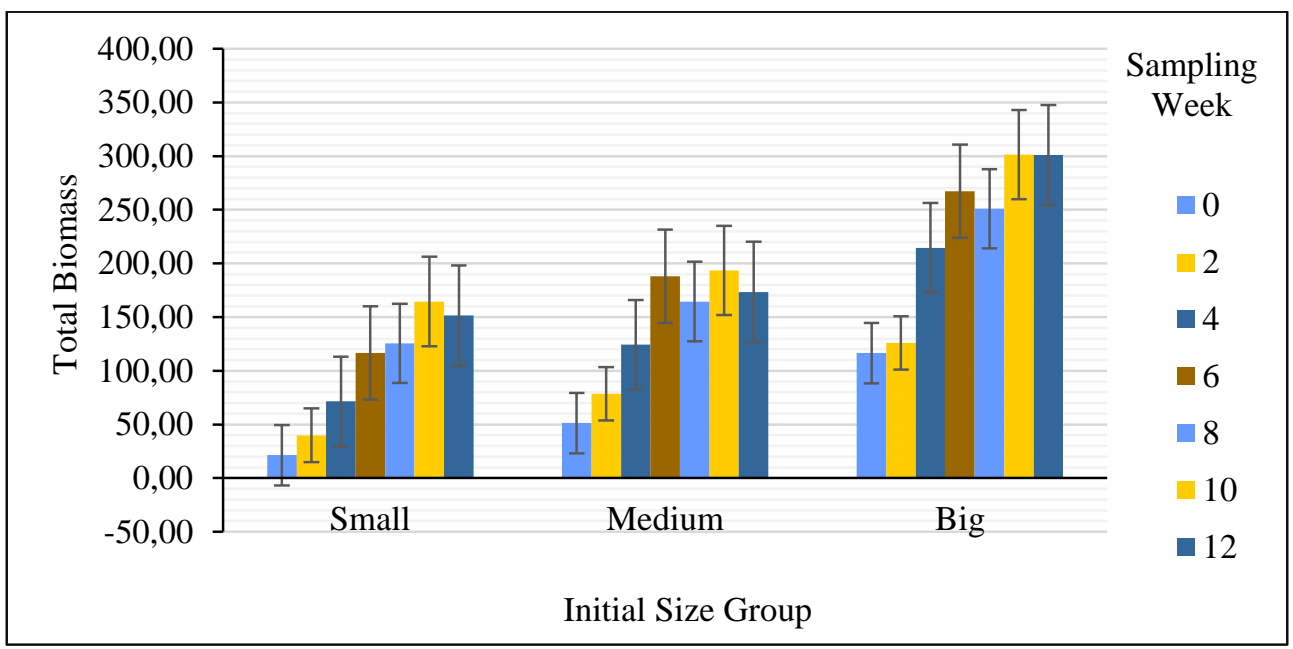

Fig 2. Total biomass of three different initial size groups of Holothuria scabra juvenile

\subsection{Survival}

Survival Rate in each treatment is shown in Figure 3. H. scabra juveniles missing from hapas were assumed as mortality. Over the experimental period, the mortality of big group was the 
lowest with survival rate $93.33 \pm 10.18 \%$. Mortality of medium group was the highest $(\mathrm{SR}=$ $77.78 \pm 26.94 \%$ ) and survival in small group was $82.22 \pm 39.06 \%$.

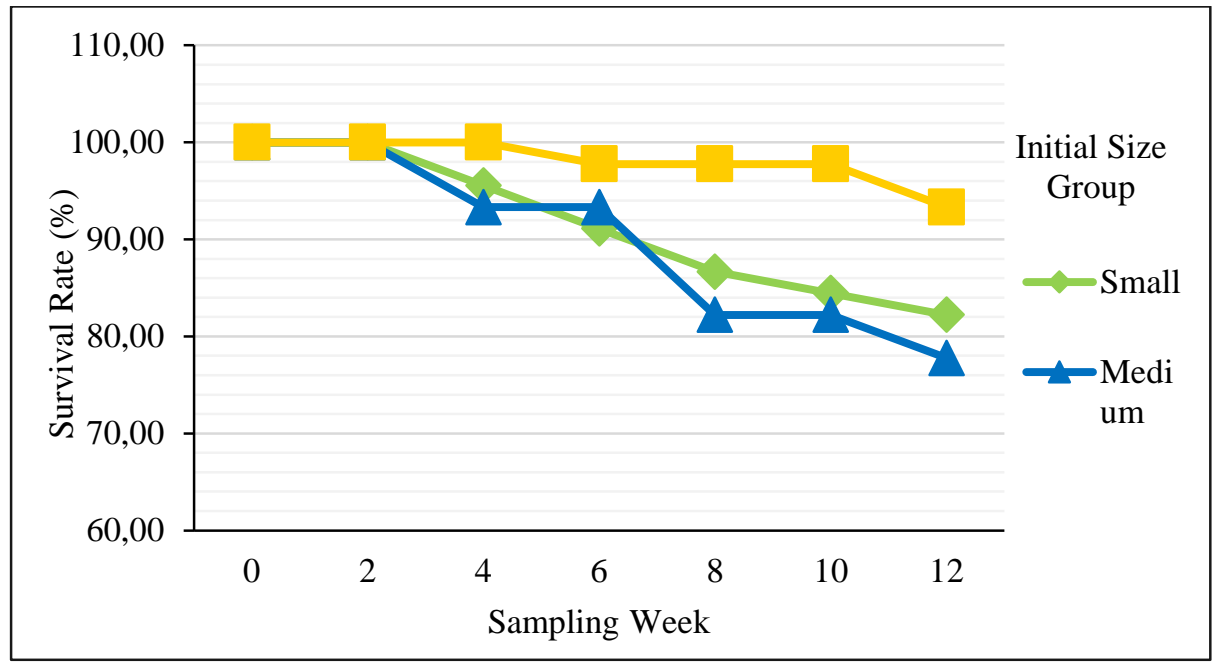

Fig 3. Survival rate of three different initial size groups of Holothuria scabra juvenile

The survival of juvenile during nursery phase and grow out in pond were various. In Vietnam, survival was $56 \%$ in 41 days [11] and $80 \%$ in 420 days [12]. Furthermore, [13] Juinio-Menez et al (2012) discovered that nursery which conducted in marine ponds hapa nets has survival 57\% in 30 days. In other research, survival was $80 \%$ in 162 days [7]. In addition, in New Caledonia, survival was $69 \%$ in 360 days [14] and $84 \%$ in 35 days [10]. [17] stated that it could be more economical when release juvenile in small size, even though low in survival rate. Release sea cucumber Apostichopus japonicus more than $2 \mathrm{~cm}$ will have a survival rate $20-30 \%$ [18].

\section{Conclusion}

Good survival and growth rate is promising that pond in Sekotong West Lombok has potential for nursery and grow out of H. scabra juveniles. The biggest initial size group has highest survival rate, otherwise, higher Weight Gain and Specific Growth Rate were in small initial group.

\section{Acknowledgments}

We would like to thank Dr Sigit AP Dwiono, Hendra Munandar, Nurhalis Tarmin, Abdul Wahab and Marine Bio Industry LIPI staff.

\section{References}

1. C. Conand. Rev. Biol. Trop, Expansion of global sea cucumber fisheries buoys exports, 65:1-10 (2017). 
2. S.W. Purcell. PLoS ONE, Value, Market Preferences and Trade of Beche-De-Mer from Pacific Island Sea cucumbers, 9(4), (2014).

3. S.W. Purcell, D.H. Williamson, P. Ngaluafe. Marine Policy, Chinese market prices of beche-de-mer: Implications for fisheries and aquaculture, 91, 58-65, (2018).

4. R.J.P. Dumalan, K.G.V. Bondoc and M.A. Juinio-Meñez. Aquaculture, Grow- out culture trial of sandfish Holothuria scabra in pens near a mariculture-impacted area, 507, 481-492, (2019).

5. C. Conand. Marine Pollution Bulletin, Tropical sea cucumber fisheries: Changes during the last decade, 133, 590-594, (2018).

6. J. Chen. Present Status and Prospects of Sea Cucumber Industry in China. In: Advances in sea cucumber aquaculture and management. FAO Fisheries Technical Paper, 463, 425p, (2004).

7. M.A. Juinio-Meñez, E.D. Tech, I.P. Ticao, J.R.C. Gorospe, C.M.A. Edullantes, R.A.V. Rioja. Fisheries Research, Adaptive and integrated culture production systems for the tropical sea cucumber Holothuria scabra, 186, 502-513, (2017).

8. N.S. Agudo. Australian Centre for International Agricultural Research, Secretariat of the Pacific Community and WorldFish Center, Nouméa, New Caledonia, Sandfish Hatchery Techniques. 44 p. (2006).

9. S.W. Purcell, C.A. Hair, D.J. Mills. Aquaculture, Sea cucumber culture, farming and sea ranching in the tropics: Progress, problems and opportunities. 368-369, 6881(2012).

10. S.W. Purcell, N.S. Agudo, PLoS ONE, Optimisation of Mesh Enclosures for Nursery Rearing of Juvenile Sea Cucumbers. 8(5), (2013).

11. R. Pitt, N.D., Duy. Breeding and rearing of sea cucumber Holothuria scabra in Vietnam. In: Advances in Sea cucumber Aquaculture and Management. FAO Fisheries Technical Paper, 333-346, (2004).

12. N.D. Duy. Large-scale sandfish production from pond culture in Vietnam. In: AsiaPacific Tropical Sea Cucumber Aquaculture. Proceedings of an International Symposium, 34-39, (2012).

13. M.A Juinio-Menez, G. de Peralta, R.J.Dumalan, C.M.Edullantes, T.Catbagan. Ocean nursery systems for scaling up juvenile sandfish (Holothuria scabra) production: ensuring opportunities for small fishers. In: Asia-Pacific Tropical Sea Cucumber Aquaculture. Proceedings of an International Sysmposium, 57-62, (2012).

14. N. Agudo. Pond grow-out trials for sandfish (Holothuria scabra) in New Caledonia. In: Asia-Pacific Tropical Sea Cucumber Aquaculture. Proceedings of an International Symposium, 104-112 (2012).

15. W. Renbo, C. Yuan. Breeding and culture of the sea cucumber, Apostichopus japonicus, Liao. In: Advances in sea cucumber aquaculture and management. FAO Fisheries Technical Paper, 463, 425, (2004).

16. S.W. Purcell. Criteria for release strategies and evaluating the restocking of sea cucumbers. In: Advances in sea cucumber aquaculture and management. FAO Fisheries Technical Paper, 463, 425p, (2004). 
17. B. Zhao, J. Yamada, N. Hirayama, S. Yamada, Journal of the Tokyo University of Fisheries, The optimum size of released reared-abalone in southern fishing ground of Akita Prefecture, 78, 217-226, (1991).

18. C. Yaqing, Y. Changqing, Songxin. Pond culture of sea cucumbers, Apostichopus japonicus, in Dalian. In: Advances in sea cucumber aquaculture and management. FAO Fisheries Technical Paper, 463, 425p, (2004). 